ORGINAL ARTICLE

\title{
Morphometric characterization of Khaya senegalensis in southern Minas Gerais State, Brazil
}

\author{
Caracterização morfométrica de Khaya senegalensis no sul de Minas Gerais, \\ Brasil
}

Luciano Helvécio Villela Reis ${ }^{1}$ (1), Lucas Fernandes Rocha ${ }^{1,2}$ (1) , Juscelina Arcanjo dos Santos ${ }^{1}$ (D), Cléber Rodrigo de Souza ${ }^{1}$ (D), Paulo André Trazzi ${ }^{3}$ (D), Lorena Oliveira Barbosa ${ }^{1}$ (D),

Dulcinéia de Carvalho ${ }^{1}$ (D)

${ }^{1}$ Universidade Federal de Lavras - UFLA, Lavras, MG, Brasil

2Universidade Estadual Paulista "Júlio de Mesquita Filho" - UNESP, Botucatu, SP, Brasil

${ }^{3}$ Universidade Federal do Acre - UFAC, Rio Branco, AC, Brasil

How to cite: Reis, L. H. V., Rocha, L. F., Santos, J. A., Souza, C. R., Trazzi, P. A., Barbosa, L. O., \& Carvalho, D. (2021). Morphometric characterization of Khaya senegalensis in southern Minas Gerais state, Brazil. Scientia Forestalis, 49(131), e3594. https://doi.org/10.18671/scifor.v49n131.16

\begin{abstract}
Understanding the morphometry patterns of planted trees is an essential forestry methodology to develop accurate silvicultural practices. The genus Khaya comprises several economically important tree species due to its high quality of the wood and it has been broadly implemented in economical plantations. Here, we analyzed the morphometric characteristics of Khaya senegalensis (Desv.) A. Juss. from 484 trees in a 4 years-old plantation located in Southern Minas Gerais state, Brazil. Therefore, we measured the diameter at breast height $(D B H)$, total height $(T H)$, and crown insertion height $(C I H)$. Using those variables, we estimated the crown length $(C L)$, the slenderness ratio $(S R)$, and the crown proportion $(C P)$. The crown quality $(C Q)$ and stem quality $(S Q)$ were estimated by visual grading. We then performed regression models for all morphometric variables to analyze the distribution of each one. The survival analysis and mean annual increment at 4 years of age (48 months) were calculated. We used the Spurr model to estimate the population volume. The $S R$ and $C L$ variables showed high levels of variation. Most morphometric variables, except for SC, presented a significant correlation with $D B H$. The $S Q$ and $C Q$ presented a linear relationship with the size of the tree. As expected, tree diameter increased with the best quality of crowns and stems. We found a low morphometric relationship between $T H$ and $D B H$. On the other hand, a linear trend was found with the increase of $D B H, C L$, and $C P$. The percentage of survival and the mean annual increment at 4 years of age were $97.2 \%$ and $3.31 \mathrm{~m}^{3} / \mathrm{ha} /$ year, respectively. The characterization revealed a good adaptation of the species within the plantation area in Southern Minas Gerais State. However, further and periodical analysis should create a robust database and make more assertive inferences of the morphometric variables.
\end{abstract}

Keywords: African mahogany; Alternative species; Silvicultural characteristics.

\section{Resumo}

Compreender os padrões morfométricos das árvores plantadas é uma metodologia florestal essencial para desenvolver práticas silviculturais precisas. O gênero Khaya compreende várias espécies de árvores economicamente importantes devido à alta qualidade da madeira e tem sido amplamente implantado em plantações econômicas. Aqui, analisamos as características morfométricas de Khaya senegalensis (Desv.) A. Juss. de 484 árvores em uma plantação de 4 anos localizada no sul do Brasil. Medimos o diâmetro na altura do peito (DAP), altura total $(\mathrm{HT})$ e altura de inserção da coroa $(\mathrm{CIH})$. Usando essas variáveis, estimamos o comprimento da copa $(\mathrm{CL})$, o grau de esbeltez (SR) e a proporção da coroa $(\mathrm{CP})$. A qualidade da copa (CQ) e qualidade do fuste (SQ) foram estimadas por meio de notas visuais. Em

Financial support: Nothing to declare.

Conflict of interest: Nothing to declare.

Corresponding author: celinarcanjo@hotmail.com

Received: 17 August 2020.

Accepted: 26 January 2021.

Editor: Paulo Henrique Müller Silva.

cC (i) This is an Open Access article distributed under the terms of the Creative Commons Attribution License, which permits unrestricted use,

c) distribution, and reproduction in any medium, provided the original work is properly cited. 
seguida, utilizamos modelos de regressão para todas as variáveis morfométricas com o objetivo de analisar a distribuição de cada variável. A análise de sobrevivência e incremento médio anual (IMA) aos 4 anos de idade (48 meses) foram calculados. Usamos o modelo de Spurr para estimar o volume da população. As variáveis $\mathrm{SR}$ e $\mathrm{CL}$ apresentaram altos níveis de variação. A maioria das variáveis morfométricas, exceto o CL, apresentou correlação significativa com o DAP. O SQ e o CQ apresentaram relação linear com o tamanho da árvore. Como esperado, o diâmetro da árvore aumentou com a melhor qualidade da copa e fuste. Encontramos uma relação morfométrica baixa entre HT e DAP. Por outro lado, foi encontrada uma tendência linear com o aumento do DAP, CL e CP. A análise de sobrevivência resultou em 97,2\% de sobrevivência aos 4 anos de idade com incremento médio anual (IMA) de 3,31 m³/ha/ano. A caracterização revelou uma boa adaptação da espécie dentro da área de plantio no Sul de Minas Gerais. No entanto, análises posteriores e periódicas devem ser realizadas para criar um banco de dados robusto e fazer inferências mais assertivas sobre as variáveis morfométricas.

Palavras-chave: Mogno africano; Espécies alternativas; Características silviculturais.

\section{INTRODUCTION}

The intensive need for forest products along with the increasing awareness about deforestation has intensified the use of forest species with economic potential. In the last decades, exotic species with superior performances have been mainly used to supply the intensive demand for timber and wood products, in which reforestation programs have become sustainable alternatives with huge economic interest (Pinheiro et al., 2011; Corcioli et al., 2016). As a result, species of the genus Khaya, popularly known as "African mahogany" have aroused interest as an option for reforestation in Brazil, since its wood presents similar characteristics to the Brazilian mahogany (Swietenia macrophylla). After the prohibition of the exploitation and commercialization of S. macrophylla in Brazil, the mahogany species have been intensely planted as an alternative (Couto et al., 2004)

Among the several species of the genus Khaya, four species are the most planted in the Brazilian reforestation programs: Khaya ivorensis, Khaya senegalensis, Khaya anthotheca, and Khaya grandiflora (Pinheiro et al., 2011). The first plantations of Khaya spp. in Brazil occurred in 1976 located in the northern region. However, the growing demand for tropical timber has been driving investments of commercial plantations throughout the country (Ribeiro et al., 2017). Furthermore, it is expected that more than 30,000 hectares have now been planted throughout Brazil (Indústria Brasileira de Árvores, 2019).

The rapid growth and the resistance of African mahogany against the shoot borer Hypsipyla grandella, the main pest of the Brazilian mahogany (S. macrophylla), contributed to the expansion of its plantations in Brazil (Ribeiro et al., 2017). According to Lunz et al., (2009), the African mahogany presents a good adaptation to the Brazilian climate that allows the plantation through almost all regions of the country. Casaroli et al. (2018) evaluated the edapho-climatic aptitude for Khaya ivorensis in the Brazilian territory and have found that the country shows great potential for the cultivation of this species since they found $56 \%$ of the Brazilian territory was considered suitable for this species, $12 \%$ presenting slight restrictions and $25 \%$ are appropriate with moderate restrictions

$K$. senegalensis presents several advantages over other species, such as better resistance against pests and water deficit during drought periods up to seven months. The species also presents efficient adaptations for regions with precipitation between 650 and 1,800 mm (Pinheiro et al., 2011). Despite being a promising economic species, the commercial plantation of $K$. senegalensis is still recent and it is in the first domestication stages (Nikles et al., 2008).

Several studies have been carried out in order to understand the behavior of African mahogany species in Brazil (Corcioli et al., 2016; Ribeiro et al., 2017; Casaroli et al., 2018). However, there is a lack of information about the best conditions for its implantation and growth, which may imply lower production and, consequently, create financial losses (Casaroli et al., 2018). Understanding the silvicultural, qualitative, and quantitative characteristics of $K$. senegalensis is an important step that may contribute to its cultivation. Additionally, it is also important to choose the best type of silvicultural intervention, the intensity of exploitation, the regeneration capacity, and growth patterns (Ribeiro et al., 2017). 
The analysis of morphometric relationships and tree dynamics is essential to improve silvicultural practices (Roman et al., 2009). Morphometry is also focused on understanding the interdimensional relationships, reconstructing the space that each tree occupies along with its development, determining the degree of competition between species, and inferring about the stability, vitality, and productivity of tree individuals (Cunha et al., 2013; Costa et al., 2016). The main morphometric characters of the tree species are diameter, area, projection, volume, crown percentage, slenderness ratio, salience, and comprehensiveness (Durlo \& Denardi, 1998).

Information about shape and dimension comprises useful data for the development of mathematical and statistical models of tree growth and competition between individuals (Hasenauer et al., 1994). In Brazil, some studies have been carried out to analyze morphometric variables considering the diameter at breast height $(D B H)$ of several species (Durlo, 2001; Cunha \& Finger, 2013; Roman et al., 2009). The crown biomass can also be determined from the study of morphometric relationships, such as total height, crown height, crown diameter with total height, and DBH (Wink et al., 2012). Given the lack of information about the Khaya spp. plantations in Brazil and the eminent importance of generating information about this species; in this work we aimed to describe the silvicultural characteristics and morphometric parameters of a four-year-old plantation of the species K. senegalensis in Southern Minas Gerais state, Brazil.

\section{MATERIAL AND METHODS}

\section{Characterization of the study area}

The area of study is located in Carmo da Cachoeira, southern of the Minas Gerais State, Brazil ( $\left.21^{\circ} 30^{\prime} 16^{\prime \prime} 45^{\circ} 07^{\prime} 23^{\prime \prime}\right)$ and presents an average altitude of 1,050 meters. The period of the growth stand had an average of annual temperature of $20.5^{\circ} \mathrm{C}$ and $1123 \mathrm{~mm}$ mean annual rainfall. The data were obtained from the Instituto Nacional de Meteorologia (INMET) database at the nearest meteorological station in the town of Varginha, located approximately $25 \mathrm{~km}$ from the plantation (Figure 1).

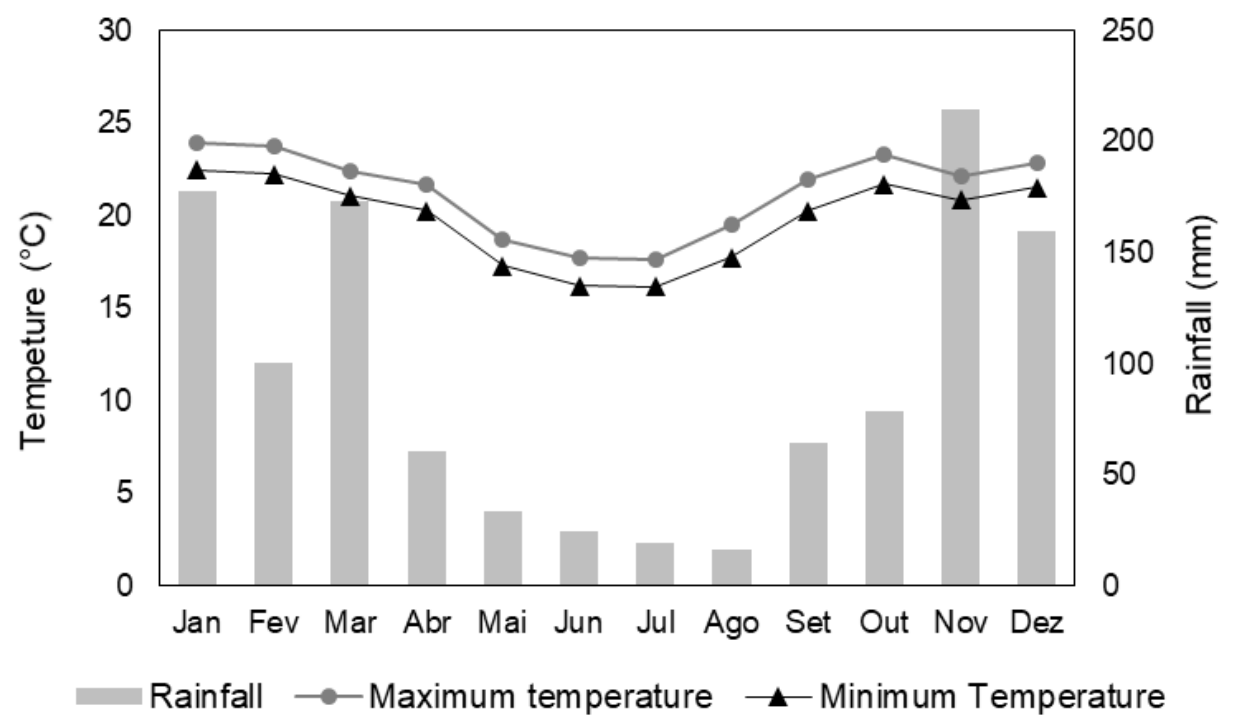

Figure 1. Monthly rainfall and averages of the maximum and minimum temperatures obtained at the weather station of Varginha, MG, from January 2014 to December 2017.

The seedlings were produced using bulk seeds from the Brazilian Institute of Forests, with unknown origin. However, most of the $K$. senegalensis seedlings in Brazil originated from the first plantations of the species in northern Brazil in the 1990s (Reis et al., 2019). The stand 
implementation occurred in January 2014, with a total area comprising 1 hectare (ha), using 500 seedlings with a line space of $5 \mathrm{~m}$ between individuals and $3.5 \mathrm{~m}$ between lines.

K. senegalensis seedlings were planted in soil classified as dystrophic Red-Yellow Latosol. The chemical analysis of the soil before the implantation of the stand was: $\mathrm{pH}=5(\mathrm{CaCl} 2) ; \mathrm{P}=8$ and $\mathrm{K}=103(\mathrm{mg} / \mathrm{dmc}) ; \mathrm{Ca}=2.2, \mathrm{Mg}=0.6, \mathrm{Al}=0.1, \mathrm{H}+\mathrm{Al}=3.6$ (cmolc/dmc); $\mathrm{MO}=2.5$ (dag/kg); $\mathrm{S}=12.2$, $\mathrm{B}=0.2, \mathrm{Zn}=3.9(\mathrm{mg} / \mathrm{dmc}) ;$ effective cation exchange capacity $(\mathrm{ECEC})=3.2$ and cation exchange capacity $(\mathrm{CEC})=6.7(\mathrm{cmolc} / \mathrm{dmc})$.

Before the implantation, the area was cleaned and weeded. According to the soil analysis and $K$. senegalensis needs, the soil received $120 \mathrm{~g}$ per meter of calcium oxide with $12 \%$ of magnesium oxide with an effective calcium carbonate rate (ECC) of 85 for the acidity correction. A fertilization using a $500 \mathrm{~g}$ per meter of single superphosphate was also performed ( $18 \%$ of $\mathrm{P}_{2} \mathrm{O}_{5}, 16 \%$ of calcium, and $8 \%$ of sulfur). After planting the seedlings were fertilized with a N-P-K formulation (20-05-20). Two cover fertilizations were carried out at 60 and 90 days after the implementation using lea same fertilization formulation. The plantation also received an application of gypsum in the total area using 1.5 tons/ha four years after planting. The control of leaf-cutting ants was performed using granular baits distributed around the stand. Invasive plants were periodically eliminated using applications of glyphosate. The trees were pruned every year starting the first year after planting to avoid tree knots. After pruning, the tree cutting wounds had a Bordeaux mixture applied to them in order to prevent diseases.

\section{Data analysis}

Four years after the stand implementation (January 2018), a total census of the dendrometric data was performed on the 484 remaining living trees. First we measured the diameter at breast height $(D B H)$ using a diameter tape. The total height $(T H)$ and crown insertion height $(\mathrm{CIH})$ were both measured using a Blume-Leiss hypsometer. Finally, we estimated the morphometric variables according to the following expressions: crown length ( $C L=H T-C I H$ ), the slenderness ratio ( $S R=H T / D A P$ ) and, crown proportion ( $C P=D A P / C L$ ). The crown quality $(C Q)$ and stem quality $(S Q)$ were analyzed using visual classification giving grades $(1,2,3,4$, and 5$)$, where 1 was given to the worse individuals and 5 to the best trees (Figures 2 and 3 ). The morphological parameters evaluated were the crown shape, leaf quantity, trunk shape, presence of bifurcations or deformations, tree vigor, tree size, and health.

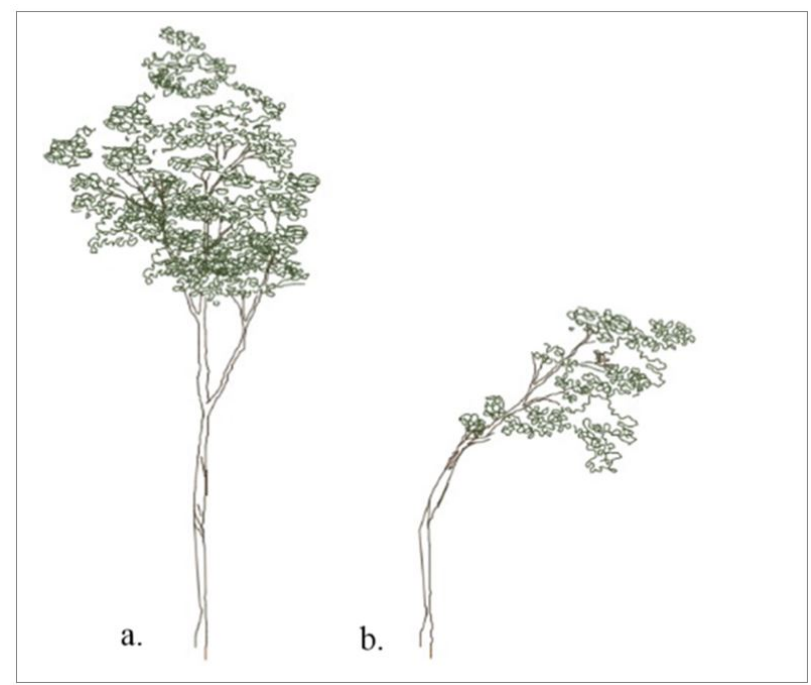

Figures 2. Stem quality. Where: a. represents trees with the best stem quality (class 5); b. represents a tree with the worst stem quality grade (class 1 ). 


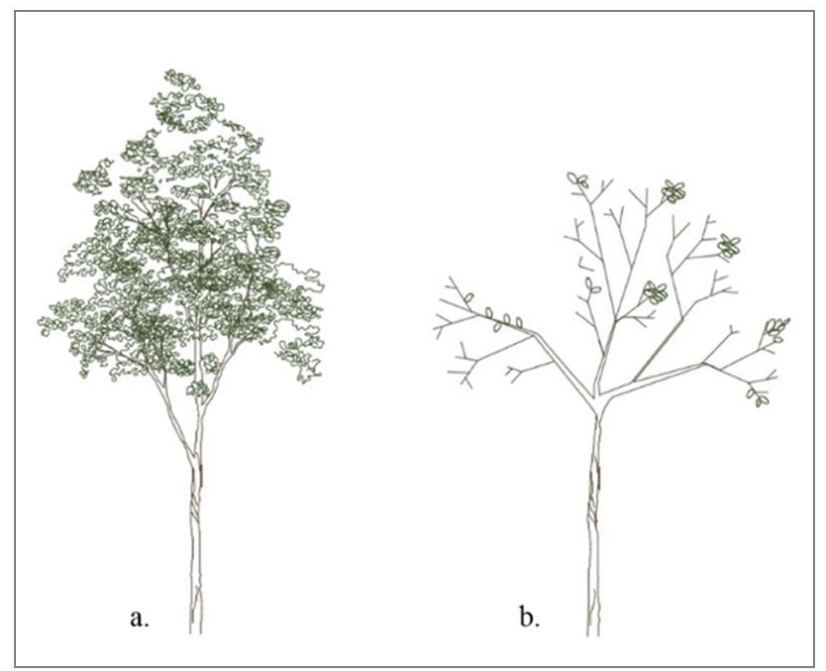

Figures 3. Crown quality. Where: a. represents trees with the best crown quality (class 5); b. represents a tree with the worst crown quality grade (class 1 ).

We applied different regression models for the analysis of the morphometric variables (Table 1). The significance coefficients were estimated using the $t$ test at a $5 \%$ probability of error. The choice of the best equation was made based on the standard error of the estimate (Syx \%) and the determination coefficient adjusted in percentage $\left(\mathrm{R}^{2} \mathrm{aj} \%\right)$. Considering the logarithmic equations, since they tend to underestimate the height values, a conversion factor was used by multiplying the estimated heights by the Meyer Factor (FM) to recalculate the standard error of the estimates, as described by Machado et al. (2015). Therefore, the Schulaegel adjustment index (SAI) was used to allow a comparison with the adjusted coefficient of determination ( $\left.R^{2} a j \%\right)$ for equations with different attributes (Machado et al., 2015).

Table 1. Mathematical models for adjusted equations considering the total height, crown insertion height, crown length, slenderness coefficient, and crown ratio of Khaya senegalensis in Southeastern Brazil.

\begin{tabular}{cc}
\hline Equation & Mathematical model \\
\hline Linear & $Y=\beta_{0}+\beta_{1} D B H+\varepsilon$ \\
Trorey & $Y=\beta_{0}+\beta_{1} D B H+\beta_{2} D B H^{2}+\varepsilon$ \\
Assmann & $Y=\beta_{0}+\beta_{1} / D B H+\varepsilon$ \\
Henricksen & $Y=\beta_{0}+\beta_{1} L n(D B H)+\varepsilon$ \\
Stoffels & $\operatorname{Ln}(Y)=\beta_{0}+\beta_{1} L n(D B H)+\varepsilon$ \\
Curtis & $\operatorname{Ln}(Y)=\beta_{0}+\beta_{1} / D B H+\varepsilon$ \\
Petterson & $Y=\left[1 /\left(\beta_{0}+\beta_{1} / D B H\right)\right]^{3}+1,3+\varepsilon$ \\
Naslund (1) & $Y=\frac{D B H^{2}}{\beta_{0}+\beta_{1} D B H+\beta_{2} D B H^{2}}+\varepsilon$ \\
Naslund (2) & $Y=\left(\frac{D B H^{2}}{\beta_{0}+\beta_{1} D B H^{2}}+1,30\right)+\varepsilon$ \\
Naslund (3) & $Y=\left(\frac{D B H^{2}}{\beta_{0}+\beta_{1} D B H+\beta_{2} D B H^{2}}+1,30\right)+\varepsilon$
\end{tabular}

Where: $D B H=$ Diameter at Breast Height; $I n=$ Napierian Logarithm; $\beta_{i}=$ Parameters of the Adjusted model $(i=0,1,2 \ldots n)$ e; $\varepsilon=$ estimation error. Source: Schneider \& Schneider (2008). 
The survival analysis of $K$. senegalensis planting was carried out using the percentage of live plants at 4 years of age in relation to the total number of seedlings planted at the time of installation of the experiment.

We calculated the mean annual increment for the $K$. senegalensis stand at 4 years of age (48 months). We used the Spurr model $\left(v=\beta_{0}+\beta_{1} *\left(D H B^{2} * T H\right)\right)$ to estimate the population volume ( $\mathrm{m}^{3} /$ hectare/year), by the parameters $\beta_{0}=0.001585$ and $\beta_{1}=0.000037$, where $D B H$ is the diameter at breast height $(1.3 \mathrm{~m})$ and $\mathrm{TH}$ is the tree total height $(\mathrm{m})$, estimated by Silva et al. (2016) in $K$. ivorensis planted in spacing $4 \times 3$ meters and age between 30 and 47 months, located in the city of Pirapora, Minas Gerais.

\section{RESULTS AND DISCUSSION}

\section{Stand description and morphometric characterization}

After grouping the diameters into five different classes, the third diameter class ( 9 and $12 \mathrm{~cm}$ ), presented a higher number of individuals (268). The lower diameter class presented only 7 individuals and the higher one comprised the other 14 individuals. The mean average of the morphometric variables is shown in table 2.

Table 2. Parameters evaluated at 4 years of age in African mahogany trees (Khaya senegalensis) located in southern Minas Gerais State, Brazil.

\begin{tabular}{cccccc}
\hline Variables & Minimum & Mean & Maximum & CV (\%) & Mean dev. \\
\hline Diameter at breast height $(D B H)$ & 2.00 & 9.26 & 15.4 & 21.55 & 2.00 \\
Total height $(T H)$ & 1.60 & 5.07 & 8.80 & 25.50 & 1.29 \\
Crown insertion height $(C I H)$ & 0.60 & 3.29 & 7.00 & 29.62 & 0.97 \\
Slenderness ratio $(S R)$ & 0.16 & 0.58 & 2.25 & 39.60 & 0.23 \\
Crown length $(C L)$ & 0.20 & 1.78 & 4.50 & 47.85 & 0.85 \\
Crown proportion $(C P)$ & 0.04 & 0.19 & 0.54 & 44.96 & 0.08 \\
\hline
\end{tabular}

Where: $\mathrm{CV}$ = Coefficient of variation; Mean dev. = Mean deviation.

The significant correlation values ranged from -0.385 (SR and $C P$ ) to 0.664 ( $C L$ and $T H$ ) (Table 3). Most of the dendrometric and morphometric variables presented a significant correlation with the diameter $(D B H)$, except the slenderness ratio. The other variables also presented significant values except for the $C L$ and $C I H(-0.002)$; and the variables $C P$ and $C I H(-0.023)$.

Table 3. Correlation matrix between dendrometric and morphometric variables in a Khaya senegalensis plantation with 4 years of age.

\begin{tabular}{cccccc}
\hline & $\boldsymbol{D B H}$ & $\boldsymbol{T H}$ & $\boldsymbol{C I H}$ & $\boldsymbol{C L}$ & $\boldsymbol{S R}$ \\
\hline $\boldsymbol{T H}$ & $0.578^{*}$ & & & & \\
$\boldsymbol{C I H}$ & $0.218^{*}$ & $0.438^{*}$ & & & \\
$\boldsymbol{C L}$ & $0.461^{*}$ & $0.664^{*}$ & -0.002 & & \\
$\boldsymbol{S P}$ & $-0.344^{*}$ & $0.540^{*}$ & $0.263^{*}$ & $0.299^{*}$ & \\
$\boldsymbol{C P}$ & 0.076 & $-0.259^{*}$ & -0.023 & $-0.284^{*}$ & $-0.385^{*}$ \\
\hline
\end{tabular}

Where: $D B H=$ Diameter at breast height; $T H=$ Total height; $C I H=$ Crown insertion height; $C L=$ Crown length $(\mathrm{m})$; $S R=$ Slenderness ratio; $C P=$ Crown proportion.

The coefficients for the adjustment of the models considering the evaluated morphometric variables are shown in table 4. The models were evaluated according to its coefficient of determination $\left(\mathrm{R}^{2}\right)$; the significance of the $F$ value; and by standard error the mean observed in the adjustment. 
Table 4. Regression models for morphometric variables of Khaya senegalensis in southern Minas Gerais State, Brazil.

\begin{tabular}{cccc}
\hline Variable & Equation & $\boldsymbol{R}_{\text {adjusted }}^{2}$ & $\mathbf{S}_{\mathbf{y x}} \%$ \\
\hline Total height $(T H)$ & $Y=6,812-15,10 / D B H$ & 0.71 & 21.74 \\
Crown insertion height $(C I H)$ & $Y=-1,382+2,933 \operatorname{Ln}(D B H)$ & 0.34 & 20.70 \\
Slenderness coefficient $(S C)$ & $Y=0,754-0,021 D B H$ & 0.12 & 21.03 \\
Crown lenght $(C L)$ & $Y=2,259-6,524 / D B H$ & 0.73 & 22.04 \\
Crown proportion $(C P)$ & $Y=0,164+0,250 / D B H$ & 0.66 & 24.52 \\
\hline
\end{tabular}

Where: $R^{2}=$ Coefficient of determination; Syx = standard error; P > F: Probability of significance ( $F$ value).

According to the model adjustment for total height and canopy insertion height, the values of the adjusted coefficient of determination ( $\left.R_{\text {adjusted }}^{2}\right)$ were low, showing that there is a low morphometric relationship between height and diameter (Table 3). The standard error $\left(S_{y x} \%\right)$ was high, which implies high levels of dispersion between observed and estimated values (Figure $4-\mathrm{A} 1$ and $\mathrm{B}$ ). A similar pattern was also found for the variable crown length $(C L)$ (Figure 4 - D1). However, a linear trend was found between the increase in diameter $(D B H)$, crown length ( $C L)$, and crown proportion (CP) (Figure 4- D2 and E2).

The slenderness coefficient (SC) presented the lowest coefficient of determination (0.12) and a standard error of $21.03 \%$ (Table 3). We found a negative exponential relationship between variables, indicating a decrease in the slenderness coefficient with an increase of diameter (DBH) (Figure 4D). So, the initial growth is higher considering the height than other variables. Besides, when the individuals reach around $6 \mathrm{~cm}$ in diameter, the trees become more stable and start to increase in diameter.

Our results indicated a high homogeneity in a $K$. senegalensis planting originating from seeds. This result is very crucial in commercial plantations of tree species, especially when the main goal is the wood production for furniture. Ribeiro et al. (2017) evaluated the production of Khaya spp. in Brazil and observed an average DBH of $18.3 \mathrm{~cm}$ for Khaya ivorensis at 4.4 years of age. However, despite the relatively close age between these stands, Khaya ivorensis and $K$. senegalensis species present different growth characteristics. Previous studies have indicated that $K$. senegalensis grows slower than Khaya ivorensis species. On the other hand, $K$. senegalensis is less demanding in water availability and consequently showing a higher capacity to withstand water deficit conditions.

According to Pinheiro et al. (2011), the total height of $K$. senegalensis at three and four years of age reaches around $2 \mathrm{~m}$ per year. In the present study, the total height achieved these expected values, indicating a good adaptation of the species to the planting site. Carmo et al. (2018) studying the initial development of the species $K$. ivorensis in an irrigated planting also located in the state of Minas Gerais, reported a 3 years-old plantation with $6.8 \mathrm{~m}$ of height and $8.25 \mathrm{~cm}$ of $D B H$. These values show a superiority of the height variable of $K$. ivorensis considering the height increment. However, our results indicated a higher mean value of diameter for $K$. senegalensis $(9.26 \mathrm{~cm})$. As discussed before, although both species are from the genus Khaya, the species present different growth patterns and were planted under different conditions, thus resulting in different growth pattern development.

The slenderness coefficient $(S C)$ presented the lowest coefficient of determination (0.12) and a standard error of $21.03 \%$ (Table 3). We found a negative exponential relationship between variables, indicating a decrease in the slenderness coefficient with an increase of diameter $(D B H)$ (Figure 4D). So, the initial growth is higher considering the height than other variables. Besides, when the individuals reach around $6 \mathrm{~cm}$ in diameter, the trees become more stable and start to increase in diameter. 

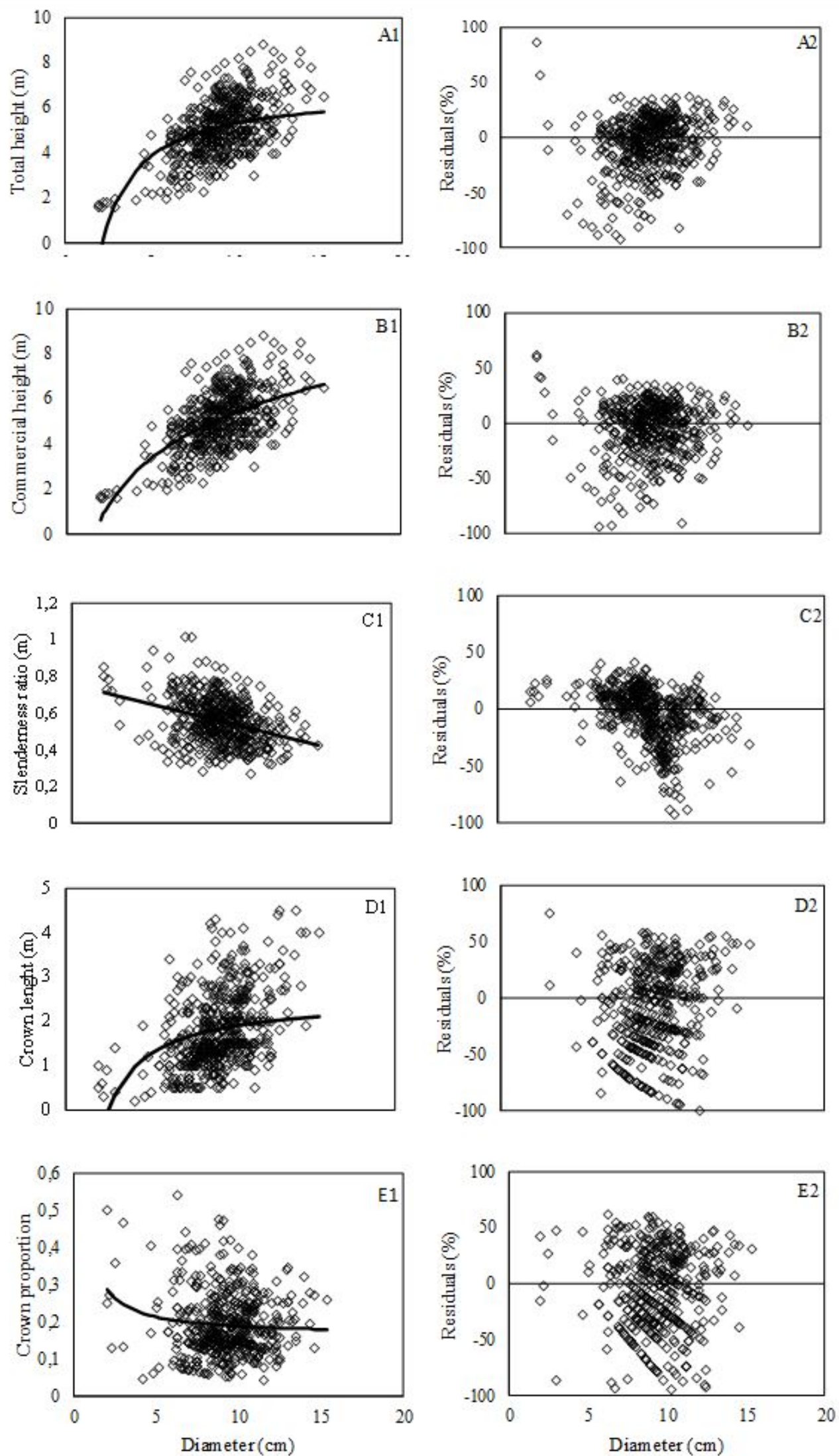

Figure 4. Observed individual (circles) of total height (A1), commercial height (B1); slenderness degree (C1); crown length (D1) and crown proportion (E1) and estimated regression curve (line) with model depending on diameter at breast height. A2, B2, C2, D2, E2: Estimated residuals according to tree diameter. 
Our results indicated a high homogeneity in a $K$. senegalensis planting originating from seeds. This result is very crucial in commercial plantations of tree species, especially when the main goal is the wood production for furniture. Ribeiro et al. (2017) evaluated the production of Khaya spp. in Brazil and observed an average DBH of $18.3 \mathrm{~cm}$ for Khaya ivorensis at 4.4 years of age. However, despite the relatively close age between these stands, Khaya ivorensis and $K$. senegalensis species present different growth characteristics. Previous studies have indicated that $K$. senegalensis grows slower than Khaya ivorensis species. On the other hand, $K$. senegalensis is less demanding in water availability and consequently showing a higher capacity to withstand water deficit conditions.

According to Pinheiro et al. (2011), the total height of $K$. senegalensis at three and four years of age reaches around $2 \mathrm{~m}$ per year. In the present study, the total height achieved these expected values, indicating a good adaptation of the species to the planting site. Carmo et al. (2018) studying the initial development of the species $K$. ivorensis in an irrigated planting also located in the state of Minas Gerais, reported a 3 years-old plantation with $6.8 \mathrm{~m}$ of height and $8.25 \mathrm{~cm}$ of $D B H$. These values show a superiority of the height variable of $K$. ivorensis considering the height increment. However, our results indicated a higher mean value of diameter for $K$. senegalensis $(9.26 \mathrm{~cm})$. As discussed before, although both species are from the genus Khaya, the species present different growth patterns and were planted under different conditions, thus resulting in different growth pattern development.

Here, the crown length variable showed a variation coefficient of $47.85 \mathrm{~m}$. This variation in forest plantations may be related to the high heterogeneity of the total height and the crown insertion length (Table 2). The crown insertion height and the stem length are interconnected by simple algebraic relations, which are related to several and important uses in forestry (Rijal et al., 2012). In fact, the crown length is fundamental to assess the tree development, since it directly affects the accumulation of leaf biomass, which is strongly correlated with the forest growth (Wink et al., 2012; Tonini \& Arcoverde, 2005). According to Costa \& Finger (2017), crown measurements are important covariates when it is desired to obtain vigorous characteristics of trees and their application in growth equations. In addition, this variable can be highly influenced by competition, and thus is suitable for the modeling of individual tree growth (Costa et al., 2016; Hasenauer, 1997).

The slenderness ratio $(S R)$ implies on tree stability because of wind resistance (Klein et al. 2017). Therefore, larger slenderness ratios indicate greater tree instability, thus being associated with several factors such as high tree competition. Therefore, this variable is indicative of the need for vegetation suppression near suppressed trees (Roman et al. 2009). The results found here showed the slenderness ratio ranging from 0.16 to 2.25 , with an average of 0.58 (Table 2). Slenderness degrees higher than " 1 " indicate that the trees are more unstable, with greater height growth in comparison to diameter growth, resulting in tall trees but with small diameter increment (Tonini \& Arcoverde, 2005; Klein et al., 2017).

The decrease in the slenderness ratio revealed by the increase in diameter of $K$. senegalensis shows a higher growth in height than in diameter (Figure 4-D). This phenomenon occurs because of the growth pattern of juvenile individuals, where the increase in height is normally greater than the increase in diameter. Since the evaluated area is a plantation for commercial purposes, the decrease in SC positively affects the stability of the trees. Plant morphometry may go through changes in different phases because of the influence of several factors, such as edaphic-climatic conditions, canopy competition, and silvicultural treatments (Condé et al., 2013). Roman et al. (2009) studied the morphometric variables and interdimensional relationships for Cordia trichotoma. These authors also found significant statistical relationships between $D B H$ and variables such as total height, crown diameter, crown length, crown proportion, and slenderness ratio.

This study is important in order to evaluate and compare the morphometric parameters of $K$. senegalensis plantations. As a secondary result, our study may also help the recommendation of silvicultural practices for the species. The heterogeneous data found here is strongly related to the relatively young age of the population as well as the population origin from seeds, which generates high patterns of genetic variability. Oliveira et al. (2018) found a 
similar result for Khaya ivorensis, reinforcing the scarce amount of information in the literature and the importance of new investigations. In fact, despite the increasing plantations of Khaya spp. worldwide, the information about morphometric characterization is very scarce.

\section{Stem and crown quality}

Overall, the trees presented a low occurrence of branches with good stem quality. Therefore, most of the trees were divided into classes 4 and 5, representing 75\% of the individuals. Specifically, class 4 comprised $47 \%$ of the trees and class 5 represented $28 \%$ of the individuals. As expected, class 1 comprised only $2.9 \%$ of the total population (14 individuals). Similarly, the crown quality also presented high quality. Thus, classes 4 and 5 comprised $74 \%$ of the individuals, from which $32 \%$ were present in class 4 and $42 \%$ were in class 5 .

The stem and canopy quality presented a linear relationship with the size of the tree. We found a tendency of increase of the tree diameter with the improvement of the stem and crown quality (Figure 5). Additionally, the crown quality was strongly correlated with the crown size and crown length, together with crown quantity (Table 3).
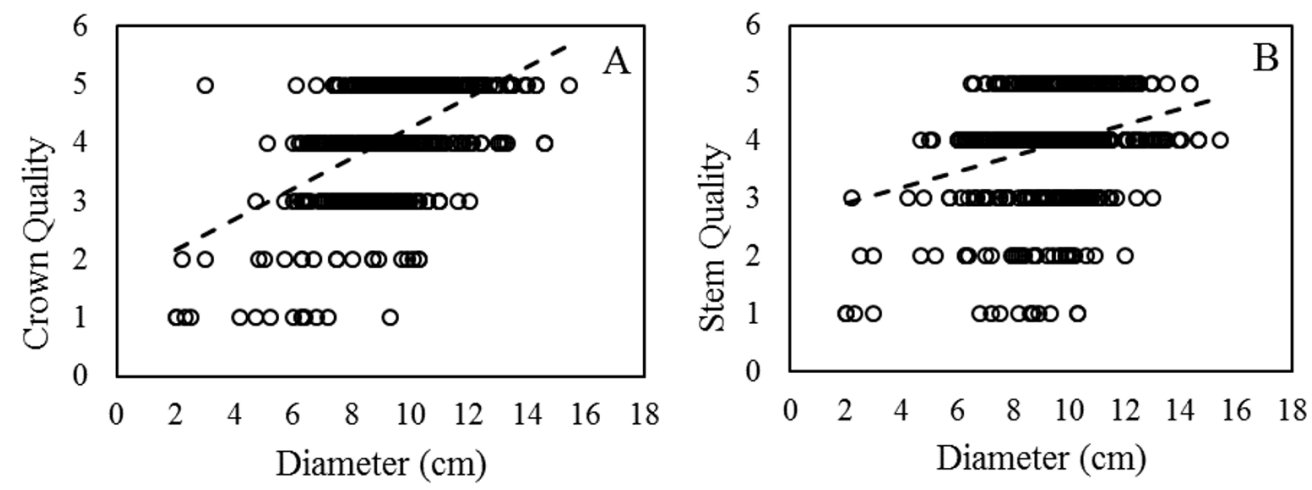

Figure 5. Dispersion graph considering the diameter at breast height $(D B H)$ as related to: (a) stem quality and (b) crown quality of Khaya senegalensis in southern Minas Gerais State.

The high patterns of stem and crown quality found herein indicates that $K$. senegalensis has a good adaptation to the climatic and edaphic conditions of southeastern Brazil, especially in southern Minas Gerais State. Although the period of time after plantation is relatively short, our study indicated that the species presents adequate characteristics to guarantee the growing demand for wood from the lamination industries. The results of crown quality also demonstrated good patterns of growth considering the spacing between plants and lines, indicating low competition between plants. The crown quality found here is strongly correlated with the size and length of the canopy and the number of leaves (Figure 2). The measurement of tree crown is a particularly important strategy for plant evaluation since its variables it is highly correlated with the diameter increment (Silveira et al., 2015).

Trees with canopies with good health conditions tend to increase its light absorption, and consequently increase its diameter and stem quality. As a result, dominated and codominated individuals normally grow more intensely in height due to the lack of light availability (Costa et al., 2016). Consequently, the characterization of crown and stem quality of trees is important to determine the canopy development over time. Silveira et al. (2015) studied a relationship between morphometry and the growth of the species Trichilia claussenii and observed that the larger the crown, the greater is the growth. Therefore, trees with higher crowns and less competition normally present high patterns of growth. Adjusting the plant density through silvicultural treatments may result in higher growth, resulting in important data for silvicultural management. 


\section{Survival and Growth Analysis}

The survival analysis showed that of the 500 seedlings planted in 2014, only 16 seedlings did not survive, resulting in a percentage of survival at 4 years of age equal to $97.2 \%$. The mean annual increment (MAI) was $3.31 \mathrm{~m}^{3} / \mathrm{ha} /$ year at 4 years of age.

The population survival analysis showed a good adaptation of the species to the climate and soil conditions of the region of Carmo de Cachoeira, MG. Kaya senegalensis prefers deep and well-drained soils, being the most drought-tolerant species compared to other Khayas, with annual precipitation estimates between 650 and $1800 \mathrm{~mm}$ with drought periods of four to seven months (Pinheiro et al., 2011; Reis et al., 2019). The region's soil class and climate seem to contribute to the survival and growth of $K$. senegalensis.

The mean annual increment (MAI) for the $K$. senegalensis stand was $3.31 \mathrm{~m}^{3} / \mathrm{ha} /$ year at 4 year of age. Carmo et al. (2018) evaluating the initial development of $K$. ivorensis in Janaúba, northern Minas Gerais state, under irrigated planting with a spacing of $5 \mathrm{~m} \times 5 \mathrm{~m}$, found IMA $2.33 \mathrm{~m}^{3} / \mathrm{ha} /$ year at 24 months and $3.37 \mathrm{~m}^{3} / \mathrm{ha} /$ year at 36 months. These results are similar to those obtained in this study, although we did not use irrigation in our stand, reinforcing the view of the good adaptation of the species to these conditions.

MAI varies according to species, planting conditions, silvicultural operations and, mainly, to the age of the stand. Young populations tend to have a lower MAl than stands at the cutting age. Our stand's IMA was similar to species of the same family, with similar age and edaphic-climatic conditions. In Brazil, the average annual increase in neem (Azadirachta indica) does not exceed $12 \mathrm{~m}^{3} /$ ha/year (Neves, 2004). Pure plantings of Cedrela fissilis are not recommended due to the attack of Hypsipyla grandella, which makes the growth of the species extremely variable, with a very low MAl, less than $4 \mathrm{~m}^{3} /$ ha/year (Angeli \& Müller, 2017). In an experiment with Brazilian mahogany (Swietenia macrophylla), not irrigated, the MAI ranged from 2.7 to $4.8 \mathrm{~m}^{3} /$ ha/year at 58 months of age, in a $4.0 \mathrm{~m} \times 1.5 \mathrm{~m}$ spacing (Fernandes et al., 2009).

Compared to other results found, the MAI of our stand was very close to that observed in other countries in stands with advanced age, such as in Ivory Coast and Malaysia, with an MAI of approximately $8 \mathrm{~m}^{3} / \mathrm{ha}$ /year around 30 years of age (Ribeiro et al., 2017), showing the potential of the species for commercial plantations in Brazil.

\section{CONCLUSIONS}

Higher growth in the diameter of $K$. senegalensis resulted in greater growth in height and crown length. On the other hand, increasing the diameter reduced the slenderness ratio, indicating a higher growth in diameter than height, resulting in higher tree stability. The qualitative evaluation indicated that the trees presented good crown and stem quality. We suggest the development of periodical measurements to obtain more robust results on the morphometric variables. In addition it is good to plant the species in new, different areas, in order to assess the applicability of the results in different environments. However, we found that $K$. senegalensis has a great potential to be cultivated in southern Minas Gerais State, Brazil.

\section{REFERENCES}

Angeli, A., \& Müller, P. H. (2017). Cedrella fissilis (Cedro). Retrieved in 2021, January 10, from http://www.ipef.br/identificacao/cedrella.fissilis.asp

Carmo, R. F., Nakajima, N. Y., Silva, S. A., \& Mattar, E. A. (2018). Desenvolvimento inicial de Khaya ivorensis em plantio irrigado. Nativa, 6(2), 159-164.

Casaroli, D., Rosa, F. D. O., Alves Júnior, J., Evangelista, A. W. P., Brito, B. V., \& Pena, D. S. (2018). Aptidão edafoclimática para o mogno-africano no Brasil. Ciência Florestal, 28(1), 357-368.

Condé, T. M., Lima, M. L. M., Lima Neto, E. M., \& Tonini, H. (2013). Morfometria de quatro espécies florestais em sistemas agroflorestais no munícipio de Porto Velho, Rondônia. Revista Agroambiente, $7(1), 18-27$.

Corcioli, G., Borges, J. D., \& Jesus, R. P. D. (2016). Deficiência de macro e micronutrientes em mudas maduras de Khaya ivorensis estudadas em viveiro. Cerne, 22(1), 121-128. 
Costa, E. A., Finger, C. A. G., \& Fleig, F. D. (2016). Influência da posição social nas relações morfométricas de Araucaria angustifolia. Ciência Florestal, 26(1), 225-234.

Costa, E. A., \& Finger, C. A. G. (2017). Efeito da competição nas relações dimensionais de Araucária. Floresta e Ambiente, 24, e20150145.

Couto, L. C., Couto, L., Watzlawick, L. F., \& Câmara, D. (2004). Vias de valorização energética da biomassa. Biomassa \& Energia, 1(1), 71-92.

Cunha, T. A. D., \& Finger, C. A. G. (2013). Competição assimétrica e o incremento diamétrico de árvores individuais de Cedrela odorata L. na Amazônia ocidental. Acta Amazonica, 43(1), 9-18.

Cunha, T. A., Finger, C. A. G., \& Schneider, P. R. (2013). Linear mixed model to describe the basal area increment for indivudual cedro (Cedrela odorata L.) trees in occidental Amazon, Brazil. Ciência Florestal, 23(3), 461-470.

Durlo, M. A. (2001). Relações morfométricas para Cabralea canjerana (Well.) Mart. Ciência Florestal, 11(1), 141-149.

Durlo, M. A., \& Denardi, L. (1998). Morfometria de Cabralea canjerana, em mata secundária nativa do Rio Grande do Sul. Ciência Florestal, 8(1), 55-66.

Fernandes, A. L. T., Faria, M. F., \& Mello Florêncio, T. A. (2009). Análise da biometria das espécies florestais teca e mogno submetidas a diferentes tratamentos de irrigação e nutrição mineral. In Anais II Seminário de Recursos Hídricos da Bacia Hidrográfica do Paraíba do Sul: recuperação de áreas degradadas, serviços ambientais e sustentabilidade (pp. 305-312). IPABHi.

Hasenauer, H. (1997). Dimensional relationships of open-grown trees in Austria. Forest Ecology and Management, 96(3), 197-206.

Hasenauer, H., Burkhart, H. E., \& Sterba, H. (1994). Variation in potential volume yield of loblolly pine plantations. Forest science, 40(1), 162-176.

Indústria Brasileira de Árvores - IBÁ. (2019). Relatório 2019. Retrieved in 2020, February 24, from https://iba.org/datafiles/publicacoes/relatorios/iba-relatorioanual2019.pdf

Klein, D. R., Hess, A. F., Krefta, S. M., Vieira Filho, M. D. H., Ciarnoscki, L. D., \& Costa, E. A. (2017). Relações morfométricas para Araucaria angustifólia (Bertol.) Kuntze em Santa Catarina. Floresta, 47(4), 501 512.

Lunz, A. M., Thomazini, M. J. T., Moraes, M. C. B., Neves, E. J. M., Batista, T. F. C., Degenhardt, J., Sousa, L. A., \& Ohashi, O. S. (2009). Hypsipyla grandella em mogno (Swietenia macrophylla): situação atual e perspectivas. Pesquisa Florestal Brasileira, (59), 45-55.

Machado, S. D. A., Accioly, Y., Nascimento, R. G. M., Silva, L. C. R., \& Cardozo, C. C. (2015). Influência do comprimento de copa na relação hipsométrica de Araucaria angustifolia. Pesquisa Florestal Brasileira, 35(83), 343-351. http://dx.doi.org/10.4336/2015.pfb.35.83.493.

Neves, E. J. M. (2004). Importância dos fatores edafo-climáticos para o uso do nim (Azadirachta indica A. Juss.) em programas florestais e agroflorestais nas diferentes regiões do Brasil (Boletim de Pesquisa Florestal, No. 49, pp. 99-107).

Nikles, D. G., Bevege, D. I., Dickinson, G. R., Griffiths, M. W., Reilly, D. F., \& Lee, D. J. (2008). Developing African mahogany (Khaya senegalensis) germplasm and its management for a sustainable forest plantation industry in northern Australia: progress and needs. Australian Forestry, 71(1), 33-47. http://dx.doi.org/10.1080/00049158.2008.10676269.

Oliveira, X. M., Ribeiro, A., Ferraz Filho, A. C., Mayrinck, R. C., Lima, R. R., \& Scolforo, J. R. S. (2018). Volume equations for Khaya ivorensis A. Chev. plantations in Brazil. Anais da Academia Brasileira de Ciências, 90(4), 3285-3298. http://dx.doi.org/10.1590/0001-3765201820170852.

Pinheiro, A. L., Couto, L., Pinheiro, D. T., \& Brunetta, J. M. F. C. (2011). Ecologia, silvicultura e tecnologia de utilização dos mognos-africanos (Khaya spp.) (102 p.). Editora UFV.

Reis, C. F., Oliveira, E. B., \& Santos, A. M. (2019). Mogno-africano (Khaya spp.): atualidades e perspectivas do cultivo no Brasil. Embrapa Florestas.

Ribeiro, A., Ferraz Filho, A. C., \& Scolforo, J. R. S. (2017). O cultivo do mogno africano (Khaya spp.) e o crescimento da atividade no Brasil. Floresta e Ambiente, 24, 1-11. http://dx.doi.org/10.1590/21798087.076814

Rijal, B., Weiskittel, A. R., \& Kershaw Júnior, J. A. (2012). Development of height to crown base models for thirteen tree species of the North American Acadian Region. Forestry Chronicle, 88(1), 60-73.

Roman, M., Bressan, D. A., \& Durlo, M. A. (2009). Variáveis morfométricas e relações interdimensionais para Cordia trichotoma (Vell.) Arrab. ex Steud. Ciência Florestal, 19(4), 473-480. 
Schneider, P. R., \& Schneider, P. S. P. (2008). Introdução ao manejo florestal (566 p.). Editora UFSM

Silva, L. F. D., Ferreira, G. L., Santos, A. C. A. D., Leite, H. G., \& Silva, M. L. D. (2016). Equações hipsométricas, volumétricas e de crescimento para Khaya ivorensis plantada em Pirapora. Floresta e Ambiente, 23(3), 362-368.

Silveira, B. D., Floriano, E. P., Nakajima, N. Y., Hosokawa, R. T., Rosot, N. C., \& Gracioli, C. R. (2015). Relação da morfometria e competição com o crescimento de Trichilia claussenii em um fragmento de floresta semidecidual. Floresta, 45(2), 373-382.

Tonini, H., \& Arco-Verde, M. F. (2005). Morfologia da copa para avaliar o espaço vital de quatro espécies nativas da Amazônia. Pesquisa Agropecuária Brasileira, 40(7), 633-638.

Wink, C., Monteiro, J. S., Reinert, D. J., \& Liberalesso, E. (2012). Parâmetros da copa e a sua relação com o diâmetro e altura das árvores de eucalipto em diferentes idades. Scientia Forestalis, 4(93), 57-67.

Authors' contributions: LHVR:Conceptualization, data curation, methodology, Writing - original draft; LFR: Conceptualization, data curation, investigation, formal Analysis, methodology, Writing - original draft, Writing review \& editing; JAS: Investigation, formal analysis, methodology, Writing - original draft, Writing - review \& editing; CRS and PAT: Investigation, formal Analysis, methodology, Writing - original draft, Writing - review \& editing; LOB: investigation, formal Analysis, Writing - original draft, Writing - review \& editing; DC:

Conceptualization, supervision, investigation, methodology, Writing - original draft; Writing - review \& editing 